\title{
ASSESSING TOURISM STUDENTS' ENGLISH PROFICIENCY COMPETENCE BASED ON ASEAN COMMON COMPETENCY STANDARD
}

\author{
Ni Nyoman Yunike Kurniarini ${ }^{1}$, Untung Waluyo ${ }^{2}$, Kamaludin Yusra ${ }^{3}$ \\ 1)Fakultas Brahma Widya/UHN I Gusti Bagus Sugriwa Denpasar \\ 23) English Department, FKIP/Mataram University \\ yunikakurnia88@gmail.com ${ }^{1}$
}

\begin{abstract}
This study is aimed to analyze the tourism students' English proficiency competence based on ASEAN Common Competency Standard (ACCS). The study used a descriptive qualitative method and the data were gained through English competency based workplace assessment for the students in three sub divisions at PDD Lombok Barat; hotel accommodation, culinary, and hotel engineering. The findings of the study showed that more than half of tourism students are still in the category of "low competence" in attaining English competencies based on ACCS.
\end{abstract}

Keywords : competence; ASEAN Common Competency Standard; assessment.

\section{Introduction}

Tourism becomes one of the main income sources for developing countries, such as Indonesia. In order to provide professional tourism services, Indonesian government has built many educational institutions in tourism field. These institutions run learning and teaching activities in vocational ways, concern more in practices as the theory based on the workplace training, for example diploma program. One of the diploma programs which develop the skills and knowledge based on local genius is Akademi Komunitas Negeri (AKN).

AKN program as the path of higher vocational education at the university level spreads in several regencies in Indonesia, including Kabupaten Lombok Barat. AKN Lombok Barat is a vocational diploma that equips its graduates with competency that are required in hospitality industry supported by sufficient basic theoretical knowledge and strong disciplinary attitudes based on potential in tourism sector. This college was guided by Bali State Polytechnic in hospitality study program which has three concentrations; hotel accommodation, culinary, and hotel engineering. These concentrations are expected to produce the graduates who have special skills for supplying the tourism professional. In order to get the best tourism professional competency, this college applies certain competency standards as the learning achievement for the learners.

Competency standards in tourism can be described as descriptions of skills, knowledge and attitude required to perform tasks and activities that appropriate with the needs of industry. The standards are also in the form of written description of what learners are expected to understand and be able to do at a specific level of their education. In hospitality field, there are a number of learning standards that should be achieved by the learners in order to fullfil the needs of industry i.e. subjects' competency standard (learning achievement that are settled by the teachers/instructors in certain subject), 
institution's learning achievement (the final achievement for whole skill and knowledge), Indonesian National Qualification level Framework (framework for the qualification that can integrate between education, training, and work experiences in order to provide job competence in accordance with the structure of various sectors), and ASEAN Common Competency Standard for Tourism Professional (ACCSTP) by applying of toolboxes in the study.

The ASEAN toolboxes, as the guideline to achieve the competency standard in tourism, are the implementation of ASEAN Common Competency Standard. These toolboxes are formulated to support Mutual Recognition Agreement (MRA) for Tourism Professional. The purpose of this mutual recognition mechanism is to facilitate mobility of tourism professionals within ASEAN based on competencebased tourism qualifications/certificates, and at the same time, improve the quality of services delivered by tourism professionals. There are 32 job titles covered under this MRA, ranging from housekeeping, front office, food and beverages services, and food production for hotel division, to travel agencies and tour operator for travel division include the skill of English.

English for tourism industry as a foreign language has its own characteristics rather than common English. It is because in tourism industry, English is the way of daily communication so that the learners should master it in their spirit to be hospitality professional. Learning English as foreign language is quiet differ from learning it as second language. As foreign language, English means to be studied by the learners who do not use it in communication in their social life or they only learn it in school or other places. In Indonesia, where English is a foreign and not a second language, the English status as a primary language of global trade and commerce and tourism in many countries become urgent problem in practical way, especially for 'answer' the needs of professional in industry.

According to David et al. (2011), great efforts are being made to close the gap between industry expectation and what academic studies offer. Since the tourism schools created by most of the world's universities in recent years are designed to deliver a holistic industryoriented education, both the employability of future professionals and the training intended for them to acquire the necessary skills have become key elements in higher education institution (Gillhespy, 2005). Based on the explanation above, the acquisition of competency standard in higher education has become a growing concern in ASEAN context of the need to enhance the same qualification of human resources as the professionals through ASEAN Common Competency Standard.

Hickman and Irwin (2013) in the research about Gap Analysis on Implementation of MRA on Tourism Professionals, have stated that Indonesia has English proficiency gap in tourism sector. The gap can be seen from tourist's complaint related directly to low levels of English, their frustration of not being able to be understood, and tourist expectations not being met as a result. Moreover, nine out of ten complaints in the tourism sector relate to service and in non-native English 
speaking countries, low level English language proficiency accounts for the majority of these complaints.

There are four rating that show level of English proficiency in communication at tourism sector. Rating 1 show large gap, that represent English language is neither integrated in tourism education nor one of the official national languages, and tourism professionals have very limited English proficiency. Rating 2 means significant gap, which English language is neither integrated in tourism education nor one of the official national languages, and tourism professionals have only rudimentary English proficiency. Rating 3 represents small gap, that English language is neither integrated in tourism education nor one of the official national languages, but tourism professionals have moderate English proficiency. Rating 4 stated insignificant gap, which means English language is integrated in tourism education or English language is one of the official national languages, and tourism professionals have good English proficiency. Based on the data from Gap Analysis on Implementation of MRA on Tourism Professionals, Indonesia takes place in rating 1 in English proficiency. It means that English proficiency ability of tourism professional is still low. The output from vocational college in tourism education are prepared to be tourism professional, therefore, it is important to analyze the students' competence in English proficiency of ASEAN Common Competency in order to get the further recommendation.

The study offers practical and theoretical benefits. Theoretically, the findings are expected to enrich and give an additional reference to other researchers in the scope of English Foreign Language (EFL). Practically, the results of the study provide a number of parties with the following significance. First, for the researcher, the study can give wider knowledge about standardization of the competencies for tourism professional especially in English subject. Furthermore, this study can give new information about how to decrease the gap between the learning outcomes and the competencies standard in ASEAN. Secondly, to the academic society, the research is expected to give contribution as a valuable source of reference to related studies which will discuss the same area in English Language Teaching. This study can give a contribution to the development of language research, especially in investigating various.

\section{Literature Review}

The ASEAN Common Competency Standard for Tourism Professional (ACCSTP) has been developed and contains 242 common competency standards for tourism professionals including English through ASEAN Member States (AMS). The CATC has been developed and is intended for delivery via Competency Based Training (CBT) and Competency Based Assessment (CBA). The CATC takes ACCSTP and packages them into qualifications across six identified tourism labor divisions, which are Food Production, Food and Beverage Services, Front Office, Housekeeping, Tour Operation and Travel Agencies. The qualifications formed align with operational though to middle management industry roles respectively. 
CBT and CBA are about preparing graduates who are ready to be professional. CBT and CBA assist them to acquire the skills and knowledge to perform at the level of competence required by industry of tourism sector. CBT and CBA also assist them to further develop the right attitude and the personality that will serve as well as they set out to meet or the expectations of their customers. In addition, CBT and CBA are not about students selecting a range of units of study, achieving a pass mark. These competencies are preparing people to work in operative, supervisory and middle management roles in the tourism and hospitality industry.

The AMS provide tourism and hospitality education and training, and whilst there are elements of CBT within courses in all AMS, there are only a few courses identified to date which are predominantly delivered as CBT and assessed using CBA principles. A significant amount of effort will need to be directed at communicating the reality of CBT and CBA to stakeholders in all AMS. Considerable resources then need to be applied in each AMS to develop trainers and educators proficient in the delivery of CBT and CBA and the use of the toolboxes designed to aid CBT and CBA. English proficiency in ASEAN Common Competency Standards has 8 competencies and 32 elements and performance criterias, as follow:

\section{Communicate in English on the telephone}

This unit deals with the skills and knowledge required to communicate effectively by telephone in a range of setting within the hotel and travel industries. It consists of 5 elements 24 perfomance criterias: take general enquiries by phone; respond to customer requests or orders; make calls to place orders; handle customer complaints; make complaints.

\section{Converse in English at a basic operational level}

This unit deals with the skills and knowledge required to converse orally in English in the workplace at a basic operational level. It consists of 6 elements and 17 performance criterias: participate in simple conversations on familiar topics with work colleagues; respond to simple verbal instructions or requests; make simple requests; describe routine procedures; express like, dislike, and preferences; identify different forms of expression in English.

\section{Deliver short oral presentation in English}

This unit deals with the skills and knowledge required to deliver a short oral presentation in English. It consists of 3 elements and 12 performance criterias: prepare for an oral presentation; deliver a short oral presentation; evaluate a short oral presentation.

\section{Gather and present product information}

This unit deals with the skills and knowledge required to gather and present product information in a range of settings within the hotel industries. It contains 3 elements and 15 performance criterias: gather and organize information; research and analyze information; present information 
Facilitate outgoing phone calls

This unit deals with skills and knowledge required to assist staff or guest to place outgoing telephone calls. It contains 4 elements and 24 performance criterias: identify elements and facilities of the host enterprise telephone system; demonstrate appropriate telephone communication skills; place outgoing calls on behalf of the enterprise; place outgoing calls on behalf of the guests.

\section{Use oral English to convey a complex exchange of ideas}

This unit deals with the skills and knowledge required to convey a complex exchange of ideas orally in English. It contains 5 elements and 20 performance criterias: discuss problem solving strategies; respond to hypothetical questions; discuss abstract concept; express opinions; discuss preferred learning styles.

\section{Write a short message in English}

This unit deals with the skills and knowledge required to write short messages in the workplace. It consists of 3 elements and 12 performance criterias: demonstrate the ability to take message from oral input; write short instructional messages; write short messages of appreciation, apology, and explanation for absence.

\section{Coach others in job skills}

This unit deals with the skills and knowledge required to coach others in job skills in a range of settings within the hotel industries workplace context. It contains 3 elements and 12 performance criterias: prepare for on job coaching; coach colleagues on the job; follow up coaching.
The ACCSTP have been developed and adopted. The CATC is based on these 242 ACCSTP. Each qualification from Certificate II through to Advanced Diploma across the six labor divisions is a package of Common Competency Standards. When comparing a qualification in any AMS with an ASEAN qualification to arrive at a decision on equivalence, the exercise of comparison must drill down below the qualification to examine what such qualification is comprised of. The comparison of competency standards contained within a qualification with the standards contained within an ASEAN qualification informs the judgment on equivalence. As the one of competency standard toward tourism field, ACCSTP should be mastered by tourism students. There are several factors that influencing the attainment of ACCSTP.

The first previous study was conducted by Arati and Prachi (2015). The study was done to understand the importance of English language skill in the Indian hospitality industry and the gaps within it. It studied the challenge as it exits in Pune city, and how AISSMS College of Hotel Management \& Catering Technology has attempted to address the issue. The study gathered the primary information by questionnaires. It underlined on the gap between existing and desired standards of English proficiency. It also highlights the attempts by the three important stakeholder (industry, teachers and students) in order to address the issue. However, it is recognizes that joint efforts need to be made to decrease the problem collectively. It is an urgent calling for innovative teaching learning practices and 
encouraging sound develop initiatives and commitment. The primary data is across the cross section of Pune hoteliers, teachers and students of the college. The findings reflect the importance of English as the universal medium of communication, and its impotance in rendering quality service and importantly.

The second previous study was conducted by Loredana and Rico (2017) on the Tourism Education Future Initiative by exploring the content of the mission statement of 84 graduate programs in tourism around the world as well as the content of 156 posts in international job search engines advertising for positions in tourism related industries. A survey conducted in several international universities, with an in depth case study applied at the University of Lugano, Switzerland revealed the results concerning the values students in tourism programs believe are important for themselves, their universities and the industry.

Third research was conducted by Avina in 2012. This study focuses on how language affects the cultural tourism experience in the international tourism context. Data were obtained through semi-structured interview of 13 studenttravelers, who traveled with the SanJose State University's study-abroad programs. The analysis of the datawas carried out within a sociolinguistic context using grounded theory methods. Findings indicated that travel motivations and the perception of significance of the language spoken at a destination were intimately connected. Tourism experience was negatively or positively affected by the level of fluency of the student-travelers in the local language. The local language can be as a facilitator of positive experiences or created a language barrier that inhibited positive experiences.

\section{Method}

This study used descriptive qualitative approach in order to give a complete understanding in the phenomenon under study. The qualitative research approach usually consists of researchers' attempt to provide explanation and/or provide an in depth meaning of a phenomenon through the use of observations, artifacts, interviews (Creswell, Hanson, Plano Clark, \& Morales, 2007). In order to support the method, the design was represented in the form of competency assessment for the students. Further, the identification of the gap lied between the skill required in ASEAN Common Competency Standards and the skills that students have at present as the support elements.

\subsection{Population and Sample}

Population of this study was the fourth semester students of Akademi Komunitas Negeri (AKN) Lombok Barat in academic year 2017/2018 with the total population of 115 students. The researcher used probablity sampling technique to select the sample by lottery number. This study used total 60 students from three sub divisions named hotel accommodation, culinary, and hotel engineering as the samples. In order to effectively conduct the research, the researcher chose to use stratification and single sampling to select students within the population that have specific characteristics that relate to the research questions that inform the study. When using stratification, the researcher 
purposefully selected members within a population that shared specific characteristics. The researcher had access and/or had selected specific names from a population utilizing single sample procedures (Creswell, 2012).

\subsection{Data Collection Procedure}

This study collected the data by document analysis and competency based assessment in classroom. To answer the research questions, the researcher needs to consider the suitable technique and tools of data collection. In this study, the researcher have collected the data through document analysis and competency based assessment. Document analysis is a form of qualitative research in which documents are interpreted by the researcher to give voice and meaning around an assessment topic (Bowen, 2009). In this study, the researcher used ASEAN Common Competency Standards (ACCS) that represent in toolboxes as the standard of assessment. This document have been analyzed to identify the English skill that must be met by the students to be professional worker in tourism.

The researcher also used competency based assessment for measuring the student ability in English skills. The skills consist of reading, writing, listening, and speaking. The result was classified as two categories: high competence ( $\mathrm{HC}$ ) and low competence (LC). It is because in the competency based assessment, there are only two categories of valuation, if the respondents were able to perform all unit competencies, they were in the category high competence. However, if the respondents were not be able to do even one single unit competency, they were in the category low competence.

The assessment instrument are adopted by the researcher based on the assessment in the ASEAN Common Competency Standard. The last, this assessment has been done by workplace based assessement in the form of role play based on basic operational hotel in each competency of three sub division at Akademi Komuniats Negeri (AKN) Lombok Barat. Hotel accommodation sub division students were performed handling reservation, check in procedure, and check out procedure; culinary sub divison students were performed food and beverages service procedure and room service procedure; hotel engineering were performed handling complaint in the case of $\mathrm{AC}$ repairement at guest room.

However, the researcher worked together with the core skill lecturer in each sub division. It is because the assessment should be in integrated skill, core skill and English proficiency. In assessing hotel accommodation students, the researcher worked together with Front Office lecturer. in culinary students' assessment, the researcher worked together with Food and Beverage Service lecturer. Then, in hotel engineering sub division, the assessment was done by the researcher and Pendingin dan Tata Udara lecturer. The researcher only focused on English competencies, while the core lecturers more specific to analyze the competency based their own subject.

\section{Results and Discussion}

The objectives of this research is to analyze the present English competence of tourism students at Akademi Komunitas Negeri (AKN) Lombok Barat. 
The data were obtained through assessment based ASEAN Common Competency Standard that represent in toolboxes. English proficiency in ASEAN Common Competency Standards has 8 competencies, 32 elements, and performance criterias in each elements. The assessment measured students' competence using the workplace based assessment (role play) by 60 respondents from 3 sub divisions (hotel accommodation, culinary, and hotel engineering). Each sub division played different role play situations in the assessment.

The respondents from hotel accommodation demonstrated reservation handling, check-in, and check out procedure. By doing these procedures, 20 respondents from hotel accommodation presented their competence in English proficiency. The results showed that 11 respondents (55\%) were in the category "low competence" and 9 respondents (45\%) "high competence". Secondly, 20 respondents from culinary sub division were assessed in food and beverages service and room service procedures. The results presented that 12 respondents $(60 \%)$ were in the category "low competence" and 8 respondents $(40 \%)$ were in the category "high competence". The last 20 respondents from hotel engineering have practiced handling complaint in the room, focused on AC repairement. The findings showed that 14 respondents $(70 \%)$ were in the category "low competence" and 6 respondents $(30 \%)$ were in the category "high competence". The summary of the findings is presented in Table 1.

Table 1. The Present English Competence of Tourism Students at Akademi Komunitas Negeri (AKN) Lombok Barat

\begin{tabular}{llll}
\hline \multirow{2}{*}{ No } & SubDivisions & \multicolumn{2}{l}{ Results (respondents) } \\
\cline { 3 - 4 } & & High Competence & Low Competence \\
\hline 1 & Hotel Accommodation & $9(45 \%)$ & $11(55 \%)$ \\
\hline 2 & Culinary & $8(40 \%)$ & $12(60 \%)$ \\
\hline 3 & Hotel Engineering & $6(30 \%)$ & $14(70 \%)$ \\
\hline
\end{tabular}

In relation to the ASEAN Common Competency Standards, "high competence" respondents were be able to do five (5) competency standards, such as communicate in English on the telephone; converse in English at a basic operational level; facilitate outgoing phone calls; gather and present product information; and write a short message in English. However, the "low competence" respondents were not be able to do three
(3) competency standards, such as deliver short oral presentation in English; use oral English to convey a complex exchange of ideas; and coach others in job skills.

Based on the results of assessment, the respondents from hotel accommodation were found to pass the assessment in 5 competency standards. Those 5 competency standards have elements which are presented in performance criterias. The performance 
criterias should be performed by the students as the parts of the unit competency. In relation to the first competency standard (communicate in English on the telephone) the students were be able to take general enquiries by phone, respond to customer requests or orders, make calls to place orders, handle customers' complaint, and make complaints.

Next, the second competency standard is converse in English at a basic operational level. In this standard, the students were be able to participate in simple conversations on familiar topics with work colleagues, respond to simple verbal instructions or requests, make simple requests, describe routine procedures, express like, dislike, and preferences, identify different form of expression in English.

For the third competency standard (facilitate outgoing phone calls), the students were be able to identify elements and facilities of the host enterprise telephone system, demonstrate appropriate telephone communication skills, place outgoing calls on behalf of the enterprise, place outgoing calls on behalf of the guests. Then, the fourth competency standard is write a short message in English. In this standard, the students were be able to demonstrate the ability to take message from oral input, write short instructional messages, and write short messages of appreciation, apology, and explanation for absence. In related to competency standard 5 (gather and present product information), the students were be able to gather and organise information, research and analyse information, and present information.

However, there are 3 competency standards which were not mastered by the students. In relation to competency standard 4 (deliver short oral presentation in English), the students were not able to prepare for an oral presentation, deliver a short oral presentation, and evaluate a short oral presentation. The next not yet attained competency standard is use oral English to convey a complex exchange of ideas. In this standard, the students were not be able to discuss problem solving strategies, respond to hypothetical questions, discuss abstract concept, express opinion, discuss preferred learning styles. In the last competency standard (coach others in job skills), the students were not be able to prepare for on job coaching and follow up coaching.

The same results also happened to culinary sub divisions. The culinary students were also not be able to three competency standard which more specific in speaking. only 8 students who were passed the competency standards and its amount lower than hotel accommodation students. Moreover, in the last sub division (hotel engineering), only a few students were be able to pass the competency standard. They only have 6 students who passed the assessment. The summary of the findings about attained competency standard and not yet attained competency standard is presented in Table 2. and Table 3. 
Table. 2. The Attained Competency Standard

\begin{tabular}{llll}
\hline No & Competency Standard & Frequency & Percentage \\
\hline 1. & Communicate in English on the telephone & 24 respondents & $40 \%$ \\
\hline 2. & $\begin{array}{l}\text { Converse in English at a basic operational } \\
\text { level }\end{array}$ & 24 respondents & $40 \%$ \\
\hline 3. & Facilitate outgoing phone calls & 24 respondents & $40 \%$ \\
\hline 4. & Write a short message in English & 24 respondents & $40 \%$ \\
\hline 5. & Gather and present product information & 24 respondents & $40 \%$ \\
\hline
\end{tabular}

Table. 3. Not Yet Attained Competency Standard

\begin{tabular}{llll}
\hline No & Competency Standard & Frequency & Percentage \\
\hline 1 & Deliver short oral presentation in English. & 36 respondents & $60 \%$ \\
\hline 2. & $\begin{array}{l}\text { Use oral English to convey a complex } \\
\text { exchange of ideas. }\end{array}$ & 36 respondents & $60 \%$ \\
\hline 3. & Coach others injob skills & 36 respondents & $60 \%$ \\
\hline
\end{tabular}

This section describes deeper explanation of the research's objectives; to analyze the present English competency of tourism students at Akademi Komunitas Negeri (AKN) Lombok Barat. The assessment has been collected from selected sample of tourism students in Akademi Komunitas Negeri (AKN) Lombok Barat to measure their English competence based on their subdivisons. The assessment was in the form of role play in several activities that represent basic operational in hotel. The language skills which were tested in this assessment include listening, writing, reading, and speaking.

Based on the results of assessment, the present English competence of students at Akademi Komunitas Negeri $(\mathrm{AKN})$ Lombok Barat is in the low category. It is proven that more than a half of students were not be able to pass three (3) from eight (8) competency standards as the requirement of tourism proffesional which stated in ASEAN Common Competency Standards. So, it can be concluded that there is a gap between the present English competence and the competency standards which should be achieved in order to be professional workers.

In relation to the ASEAN Common Competency Standards, "high competence" respondents were be able to do five (5) competency standards, such as communicate in English on the telephone; converse in English at a basic operational level; facilitate outgoing phone calls; gather and present product information; and write a short message in English. However, the "not yet competent" respondents were not be able to do three (3) competency standards, such as deliver short oral presentation in English; use oral English to convey a complex exchange of ideas; and coach others in job skills.

Based on the results of assessment, the respondents from hotel accommodation could pass the assessment in 5 competency standards. Those 5 competency standards have elements were represented in performance criterias as the steps in working for the students. In relation to the first competency standard (communicate in English on the telephone) the students 
were be able to take general enquiries by phone, respond to customer requests or orders, make calls to place orders, handle customers' complaint, and make complaints. Next, the second competency standard is converse in English at a basic operational level. In this standard, the students were be able to participate in simple conversations on familiar topics with work colleagues, respond to simple verbal instructions or requests, make simple requests, describe routine procedures, express like, dislike, and preferences, identify different form of expression in English. For the third competency standard (facilitate outgoing phone calls), the students were be able to identify elements and facilities of the host enterprise telephone system, demonstrate appropriate telephone communication skills, place outgoing calls on behalf of the enterprise, place outgoing calls on behalf of the guests. Then, the fourth competency standard is write a short message in English. In this standard, the students were be able to demonstrate the ability to take message from oral input, write short instructional messages, and write short messages of appreciation, apology, and explanation for absence. In related to competency standard 5 (gather and present product information), the students were be able to gather and organise information, research and analyse information, and present information.

However, there are 3 competency standards were not mastered by the students. In relation to competency standard 4 (deliver short oral presentation in English), the students were not be able to prepare for an oral presentation, deliver a short oral presentation, and evaluate a short oral presentation. The next not yet attained competency standard is use oral English to convey a complex exchange of ideas. In this standard, the students were not be able to discuss problem solving strategies, respond to hypothetical questions, discuss abstract concept, express opinion, discuss preferred learning styles. In the last competency standard (coach others in job skills), the students were not be able to prepare for on job coaching and follow up coaching.

The first sub division, hotel accommodation, has 11 respondents who are not competent yet based on their performance in assessment (reservation handling, check-in procedure, and checkout procedure). Most respondents are 'weak' in speaking skills especially in vocabulary and grammar. The vocabularies relates to how they communicate with the guest by asking questions about personal information and explaining about the check in or check out information. For instance, the respondents forgot to ask about payment method and special request. This is also happen in telephone conversation while handling the reservation. A conversation on the telephone also use four skills in different way because it does not allow the speaker and the operator to use face to face communication. Beside speaking skill, listening also become the problematic performance for them. They have to pay more attention what the guest were saying, understand the points and make a decision. In writing skill, there are also some weakness that is shown by the respondent. They are also less competent in writing criteria. It can be stated because they have several mistakes in filling the reservation and registration form, such as guest name, date occupancy, etc. Several 
respondents have mistake to write down the information from the guest. Compared with the other skills, reading skill has the smallest problem based on their performance in the assessment.

The same results were also happened in culinary sub divisions. The culinary students were also not be able to three competency standard which more specific in speaking. only 8 students who were passed the competency standards and its amount lower than hotel accommodation students. In the second sub division, culinary, the respondents who are in the category not yet competent in amount of 8 respondents. Based on the performance, most of respondents are not be able to do their basic operational job in food and beverages service and room service sections. Speaking becomes the most difficult skill to do when doing the assessment. Most of respondents are lack of vocabularies and have mistake in grammar. In this assessment, speaking and writing becomes the difficulties for the respondents.

Moreover, in the last sub division (hotel engineering), only a few students were be able to pass the competency standard. They only have 6 students who passed the assessment. The results show 14 repondents are not competent yet in English proficiency based on ASEAN Common Competency Standard. The respondents have done complaint handling procedure by voice contact (telephone) and direct contact in the guest room. In the role play, the repondents are usually more focus on technical work rather than respond the conversation. It is obviously that hotel engineering repondents are "weak" in English skills, especially speaking skill.
This result is in line with Mele (1994) who stated that if students' performance in one receptive skill (listening) was high, their performance in the other receptive skill (reading) took a similar pattern to that in one productive skill (speaking). Their performance in the other productive skill (writing) was low. Furthermore, Mele also added considering the fact that the visual/literate modality skills (reading and writing) rather than the auditory/oral modality skills are the ones emphasized, taught and formally examined at this level in school, it should be significant to identify whether the results of the students' performance in the visual/literate skills.

Based on the presented findings that show gap between the student competence toward the ASEAN Common Competency Standard, the next discussion is about factors that hinder the attainment of the competency standard. There are several factor affecting students' attainment in learning English, such as students factors, teachers factors, and institutional factors. There are two factors that hinder the students in achieving the competency standard, internal and external factors. The results of this research show that internal factors have more contribution in hindering the attainment of ASEAN Common Competency Standard and it is being increased by external ones too.

Moreover, the students at Akademi Komunitas Negeri (AKN) Lombok Barat separated in three sub divisions which have two classes in each of them. The students are not separated by the different level of ages, but they are included in one class. It is opposite with the opinion that students with different 
ages level should have different approach in learning foreign language. Therefore, age becomes one of the individual difference that hinder the attainment of ASEAN Common Competency Standard. It is proved that different level of ages can be factors that hinder the attainment if it does not manage well.

Further, this difference will affect the lesson plan and process, the materials, and which techniques will apply. Generally, there are three levels of learners' language level i.e. (a) beginner (have competence in basic English for example vocabularies); (b) intermediate (have basic competence in speaking and writing); (c) advanced (have ability in communication with native speaker, basic competence in reading and listening). It can be stated that students at Akademi Komunitas Negeri (AKN) Lombok Barat were in the level of beginner.

Teaching techniques and activities which applied in learning process can be different in each level. According to Harmer (2001:45), it is easier for beginner learners to perceive their progress rather than intermediate learners who are usually have subtle progress. Therefore, the teacher has to set clear challenging goals also achievable activities which are interesting to them. The teacher may use simple vocabulary by reading one by one word for beginner level, while for advanced, they may use more complex activities for example in discussion. The languages used in learning process are also influenced by the learners' language level, from the complexity and fluency; it depends on the learners' level. Then, the choice of the topic, books or modules also use different type languages that appropriate to the levels. The advanced learners can be deal with abstract items but for beginners' level, the topics or books should be simpler. This setting is very important to attract the students to do their best in attaining the competency standard. The uniqueness of the students always play the central role in learning foreign language, so that there should be more attention in applying material, teaching method and activities in the learning process. This is in line with Mc. Donough (1981:130) who stated that all teachers know that some of their students will coup easily with the learning materials and activities and some will not. Some will succeed and others will not. Therefore, individual differences of the students have implication for the classroom management.

\section{Conclusions}

After analyzing the assessments' results above, it can be concluded that less than half (50\%) students at Akademi Komunitas Negeri (AKN) Lombok Barat are in the category "low competent" in attaining the ASEAN Common Competency Standard as the standard of English prociency in tourism field. The results show that $55 \%$ students of hotel accommodation; $60 \%$ students of culinary; and $70 \%$ students of hotel engineering were found "low competence" and the rest in the category "high competence". The students have more difficulties in productive skill (speaking and writing) rather than receptive skill (listening and reading). The findings and discussions show the correlation between theory and the findings. Therefore there are some suggestions: (a) It is important for the lecturer to know the students' competence 
In English proficiency for attaining the ASEAN Common Competency Standard as the ASEAN standard for tourism field; (b) The future researchers may explore different point of view to do future research and relate it with the previous studies, such as hindering factors that come from teachers' or institution; (c) The future researchers are suggested to focus more about the elements and

\section{References:}

Creswell, J. W. (2009). Research Design: Qualitative, Quantitative, and Mixed Methods Approaches. Newbury Park: Sage.

Flick, U. (2006). An Introduction to Qualitative Research. London: Sage.

Good, T. M. and Brophy, J. (1990). Educational Psychology: A Realistic Approach (fourth edition). London. Longman.

Harmer, J. (2001). The Practice of English Language Teaching. Third Edition England: Pearson Education.

Hickman, A. and Irwin, J. (2013). Gap Analysis on Implementation of MRA on Tourism Professionals. performance criteria in English proficiency based on ASEAN Common Competency Standard as the standard of tourism field in order to master it and develop research about this topic; (d) The future researchers are suggested to analyze the English competence that is integrating with core skill in tourism for professional worker at industry.

Final Report. ASEAN Australia Development Cooperation Program Phase II (AADCP).

Johnson, B. and Turner, L.A. (2003). Data Collection Strategies in Mixed Method Research. In A. Tashakkari \& C. Teddie (Eds.) Handbook of Mixed Method in Social and Behavioral Research (pp. 279-319). Thousand Oaks. CA: Sage.

Knupfer, N. N. and McLellan, H. (1996). Descriptive Research Methodologies. New York: MacMillan.

Mc. Donough, H. (1981). Psychology in Foreign language Teaching. London. Longman. 